Janis Lazdins, Dr. iur., Professor

University of Latvia, Latvia

\title{
THE ORIGINS OF A CIVIL SOCIETY BASED ON DEMOCRATICALLY LEGITIMATE VALUES IN BALTICS AFTER ABOLITION OF SERFDOM
}

\begin{abstract}
Summary
The article is dedicated to the origins of civil society in the Latvian-populated Baltic Governorates during the rule of the Russian Empire. Reforms linked to the abolition of serfdom at the beginning of the $19^{\text {th }}$ century turned into the point of reference for this process. The genesis and evolution of awareness of legitimate democratic traditions were gradual, concurrent with decreasing impact of the estate on the society of a civil parish. Emancipation of peasants was closely related to accumulation of experience in the governance of a civil parish and the right to administer justice independently in lower instance courts. Until the First World War (1914), the administration of a civil parish for the majority of Latvians turned into a school of the rule of law and understanding of democracy.
\end{abstract}

Keywords: abolition of serfdom, liberation of serfs, peasant laws, freedom, civil parish, parish court, legitimate values, democracy

\section{Introduction}

At the end of the $12^{\text {th }}$ century and in the $13^{\text {th }}$ century, the lands of the Balts and Livs were colonised by Catholic Christians (predominantly from Germany) ${ }^{1}$, who were spreading the Christian faith. During the roughly century-long military skirmishes, the majority of local aristocracy perished or left their homeland. The remaining gradually assimilated into the German culture. German turned into the language of culture and education but German knighthood - into masters of the land.

The Latvian nation formed on the basis of Baltic and Liv peasants. Languages of the Baltic tribes merged into one Latvian language over a couple of centuries. Literary

\footnotetext{
1 Šterns I. Latvijas vēsture. 1180-1290. Krustakari [The History of Latvia 1180-1290. Crusades]. Rīga: Latvijas vēstures instītūta apgāds, 2002; Seraphin E. Geschichte Liv-, Est- und Kurlands von den "Aussegelung" des Landes bis zur Einverleibung in das russische Reich. I. Band. Die Zeit bis zum Untergang livländischer Selbständigkeit [History of Livonia, Estonia and Courland from the "discovering" of the country to its incorporation into the Russian Empire. Vol. 1. The time until the loss of independence of Livonia]. Reval: Verlag von Franz Kluge, 1895, S. 3-109.
} 
Latvian can be spoken of starting with the $16^{\text {th }}-17^{\text {th }}$ centuries. ${ }^{2}$ Simultaneously with the formation process of the Latvian nation, the majority of peasants lost not only land but also personal freedom. ${ }^{3}$

The abolition of serfdom in the Baltic Governorates of the Russian Empire was a historical event for Latvians (1817-1819). The majority of people regained the rights of a free person. ${ }^{4}$ The author discerns in the abolition of serfdom also the first step on the path towards the proclamation of the Latvian State (1918). If serfdom had not been abolished at the beginning of the $19^{\text {th }}$ century, it is highly unlikely that the Republic of Latvia would have been proclaimed at the beginning of the $20^{\text {th }}$ century. ${ }^{5}$

The Russian Empire was governed in accordance with the principles of monarchy. Latvia was proclaimed as a democratic republic. ${ }^{6}$ This proves that awareness of democratically legitimate values existed before the state was established. In the current article, the author aims to identify those factors of influence that for the majority of Latvians became the basis for understanding of democratically legitimate values following the abolition of serfdom. The article is a limited-scope study. Therefore, the contribution of the New Latvians (jaunlatvieši $)^{7}$ and members of the New Current movement (jaunsträvnieki) ${ }^{8}$ to the formation of the Latvian national identity remains outside the framework of this article.

2 Bušs O., Jansone I. Ieskats latviešu valodas vēsturē (no pirmsākumiem līdz 20. gadsimtam) [Insight into the History of the Latvian Language (from Origins to the $20^{\text {th }}$ Century)]. In: Latvija un latvieši. II sējums [Latvia and Latvians. Vol. II]. Rịga: Latvijas Zinātnuu akadēmija [Latvian Academy of Sciences], 2018, pp. 117-128.

3 Lazdiņš J. Dzimtbūšanas atcelšana, pagasta sabiedrības organizācija un nacionāli valstiskas domāšanas pirmsākumi [Abolition of Serfdom, Organisation of Parish Society and the Origins of Nation-State Thinking]. In: Latvieši un Latvija. II sējums. Valstiskums Latvijā un Latvijas valsts izcininitā un zaudētā [Latvians and Latvia. Vol. II. Statehood in Latvia and the State of Latvia - Won and Lost]. Rīga: Latvijas Zinātṇu akadēmija [Latvian Academy of Sciences], 2013, pp. 179-182; Prutz H. Der Kampf um die Leibeigenschaft in Livland [The Struggle for Serfdom in Livonia]. München: Verlag der Königlich Bayerischen Akademie der Wissenschaften, 1916, S. 24-28.

4 In Latgale or the three Latvian districts of the Governorate of Vitebsk of the Russian Empire, serfdom was abolished considerably later (1861). Seе Манифестъ. - О Всемилостивейшемъ дарованіе крепостнымъ Аюдямъ правъ состоянія свободныхъ сельскихъ обывателей, и объ устройстве ихъ быта [Manifesto. - On the All-Gracious Granting to the Serfs of the Right to the Status of Free Rural People and Their Living Conditions], (19.02.1861): Law of the Russian Empire. Полное собраніе законовъ Россійской имперіи. ОтАемение первое [Complete Collection of Laws of the Russian Empire. First Chapter], т. XXXVI, № 36650, 1861. Available at: http://nlr.ru/e-res/ law_r/content.html [last viewed August 31, 2019].

5 Lazdiņš J. 2013, pp. 173-196.

6 Latvijas pilsoniem! (18.01.1918) [To the Citizens of Latvia! Declaration by the Republic of Latvia]. Pagaidu Valdỉbas Vēstnesis [Herald of the Provisional Government], 1918. g. 14. (1.) decembrī, Nr. 1; Latvijas Tautas padomes politiskā platforma [The Political Platform of the Latvian People's Council] (18.01.1918): The Provisional Law of the Republic of Latvia. Pagaidu Valdibas Vēstnesis [Herald of the Provisional Government], 1918. g. 14. (1.) decembrī / Latvijas Valsts Vēstures arhìvs [The National Archives of Latvia] (hereafter - LVVA), 1307. fonds (hereafter - f.), 1. apraksts (hereafter - apr.), 327. lieta (hereafter - 1.), pp. 27-29.

7 Developed national culture and fought against the dominance of the Baltic German culture.

8 Promulgators of social democratic-Marxist views. 


\section{Origins of the understanding of legitimate democratic values}

1.1. The reforms, maintained in the spirit of humanism, were launched shortly before the abolition of serfdom. This process was ushered in by the adoption of the law of 20 February 1804 - the Law on Peasants in the Governorate of Livonia. ${ }^{9}$ The purpose of the law was not only to align the relationships between the estate and the land used by peasants but also to start the process of peasant emancipation. To implement the reform, a special system of peasant courts was created. Instead of being just an extra in judicial proceedings, a peasant had to turn into the party in charge of legal proceedings in lower courts. To highlight the role of peasant judges in administering justice, Alexander I Romanov (Александр I Романов, 1801-1825) noted in his epistle to Landrat Friedrich von Sivers:

The goal of justice for the peasants will not be reached if every gentleman [landlord] will be recognised as their [the peasants'] sole judge. This post ought, justifiably, to be entrusted to a judge selected by the peasants themselves. ${ }^{10}$

The beginning of peasant emancipation process by far did not mean its prompt completion to the full extent. The Emperor had intended only to limit the power of the estate rather than abolish it. Therefore, the peasants' court (civil parish) as the first-instance court consisted of judges belonging to the peasant class. In each composition of the court, one judge from among peasants for the term of three years was elected by the landlord or the leaseholder of the estate, the second, by majority vote, was elected by farm owners, and the third - by workers (servants). ${ }^{11}$ The democratic significance of electing the majority of peasant judges was decreased by retained supervision of the estate over civil parish courts. A judgement by the peasant court had to be approved by the landlord, the leaseholder or the manager of the estate. ${ }^{12}$ In religious parish courts (приходской суд) as the courts of the second instance and land courts (ландгерихm) as third-instance courts ${ }^{13}$, peasants performed only the duties of assessors. Peasants were not involved in the highest court of the Governorate $\left(\right.$ Гофгерихm). ${ }^{14}$

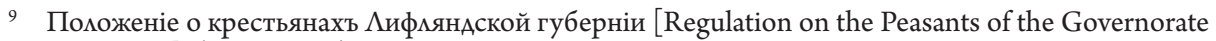
of Livonia] (20.02.1804): Law of the Russian Empire. Полное собраніе законовъ Россійской имперіи, съ 1649 года [Regulation on the Peasants of the Governorate of Livonia since 1649], 1804-1805, т. XXVIII, № 21162. Available at: http://nlr.ru/e-res/law_r/content.html [last viewed August 31, 2019].

10 Cited from: Tobien A. Die Agrargesetzgebung Livlands im 19. Jahrhundert. I. Band: Die Bauerverordnung von 1804 und 1809 [The Agricultural Legislation of Livonia in the $19^{\text {th }}$ Century. Vol. I: The Peasant Law of 1804 and 1809]. Berlin: Puttkammer \& Mühlbrecht, 1899, S. 163.

11 Положеніе о крестьянахъ Аифмянаской губерніи [Regulation on the Peasants of the Governorate of Livonia] (20.02.1804), Art. 80, 82.

12 Ibid., Art. 90.

13 Land court was the first instance court for hearing cases of peasants and nobility.

14 Положеніе о крестьянахъ Аифмянаской губерніи [Regulation on the Peasants of the Governorate of Livonia] (20.02.1804), Art. 100, 118, 125, 128, 130 etc. 
The right of a Latvian peasant to vote and to be elected to positions in a lower court should not be underestimated. Henceforth, a judge had to be able not only to read and write but also to make a judgement and provide legal reasoning for it. The 1804 Law on Peasants in Livonia Governorate did not abolish serfdom. Thus, the basic pre-requisite for a democratically organised society - human liberty - was not attained.

1.2. In the Latvian-populated Baltic Governorates, serfdom was abolished on the basis of two laws:

1) by the law of 25 August 1817 in the Governorate of Courland (hereafter the 1817 Law on Peasants in the Governorate of Courland) $)^{15}$;

2) by the law of 26 March 1819 in the Governorate of Livonia (hereafter the 1819 Law on Peasants in the Governorate of Livonia) ${ }^{16}$.

The abolition of serfdom was both a triumph for the Enlightenment ideas of natural rights in respect to personal freedom, as well as a pre-requisite for transition to new economic relations, i.e. capitalism. ${ }^{17}$ Regretfully, not everything related to the abolition of serfdom can be seen in a positive light. Peasants were granted freedom without the right to retain the right to use the land. From the perspective of nobility's interests, the following principle was implemented - the land is mine, yours is the time (that is, freedom) (Land mein und Zeit dein ${ }^{18}$ ) or - land to the landlord, freedom to the peasant. Thus, for farm owners in the Baltic Governorates, the abolition of serfdom turned into "the same freedom as birds in the forest have to be chased from to tree"19 or the so-called freedom of a bird. The author holds that such terms of the agrarian reform, undoubtedly, were unjust. However, this negative aspect of "emancipation" and also retaining of the nobility's privileges should not be

15 Учрежденіе о Курмянаскихъ рестьянахъ / Kurländische Bauer-Verordnung [Decree on the Peasants of Courland] (25.08.1817): Law of the Russian Empire. Полное собраніе законовъ Россійской имперіи, съ 1649 года [Complete Collection of Laws of the Russian Empire since 1649], 1817, т. XXXIV, № 27024. Available at: http://nlr.ru/e-res/law_r/content.html [last viewed August 31, 2019].

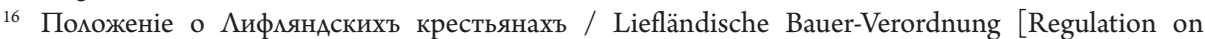
the Peasants of Livonia] (26.03.1819): Law of the Russian Empire. Полное собраніе законовъ Россійской имперіи, съ 1649 года [Complete Collection of Laws of the Russian Empire since 1649], 1819, т. XXXVI, № 27735. Available at: http://nlr.ru/e-res/law_r/content.html [last viewed August 31, 2019].

17 Lazdiņš J. Abolition of serfdom and organisation of civil parish communities. In: Latvia and Latvians. Riga: Latvian Academy of Science, 2018, Vol. II, pp. 329-336.

18 Sivers J. von. Zur Geschichte der Bauernfreiheit in Livland [On the History of Peasant Freedom in Livonia]. Riga: Nicolai Kymmel's Buchhandlung, 1878, S. 68.

19 Cited from: Ābers B. Vidzemes zemnieku "putna brīvība” pēc 1819. g. likuma ["The Bird's Freedom” of Vidzeme's Peasants after the Law of 1819]. Tieslietu Ministrijas Vēstnesis [Herald of the Ministry of Justice], 1936, No. 3, p. 463. 
the sole focus, as often seen in Latvian scholarly writing. ${ }^{20}$ It should be understood that a serf, prior to "emancipation", was seen as a chattel in the meaning of the Roman law. ${ }^{21}$ For a good reason, Prof. Jānis Zutis introduced the term - serf-slaves ${ }^{22}$, whereas Leonid Arbusow wrote about serfdom bordering on slavery ${ }^{23}$. At the end of the $18^{\text {th }}$ century, humanist August Wilhelm Hupel recorded the unenviable conditions of a serf, as follows:

Moonlighters (rightless workers) and their children are here occasionally sold or bartered for other objects - horses, dogs, pipe bowls, etc.; people here are not as expensive as Negroes in the American colonies, a bachelor may be bought for 30-50 roubles, but if he has a trade (or semblance of one) such as cook, weaver, etc., the price might be as high as 100 roubles; the same amount buys an entire family (parents and their children); a serving girl rarely fetches more than 10 roubles, and a child, approximately 4 roubles). ${ }^{24}$

A peasant's personal freedom changes the social relations that have developed over centuries. ${ }^{25}$ The law, rather than the landlord's will, had to become the yardstick for every action. "Emancipation" laws, on the level of positive law, defined peasants' rights, inter alia, the order for administering the civil parish.

The civil parish assembly was convened upon the proposal by the parish elder or the civil parish court with the permission of the estate (board/police) or upon the estate's initiative. ${ }^{26}$ All peasants had to be invited to the parish assemblies. Only one category (

20 Ābers B. Vidzemes zemnieku stāvoklis 19. gs. pirmā pusē [The Situation of Vidzeme's Peasants in the First Half of the $19^{\text {th }}$ Century]. Rigan: Izdevusi grāmatu apgādniecỉba A. Gulbis, 1936, pp. 120-128; Dunsdorfs M. Baltijas muižnieciba laikmetu maiņā [The Baltic Nobility in the Change of an Era]. Rìga: Zinātne, 1986; Zutis J. Vidzemes un Kurzemes zemnieku brīvlaišana XIX gadsimta 20. gados [Setting Free of Vidzeme and Kurzeme Peasants in the 20s of XIX Century]. Rigā: Latvijas Valsts izdevnieciba, 1956, etc.

21 Vīgrabs J. Landrāta Rōzena 1739. gada deklarācija par Vidzemes dzimtkungu tiesībām uz zemnieku miesu un mantu [The Declaration of Landrat Rosen of 1739 on the Rights of Vidzeme Feudal Lords to the Body and Property of Peasants]. Rīgā: A. Gulbis, 1937, p. 94; Švābe A. Zemes attiecības un zemes reformu vēsture Latvijā [Land Relationships and the History of Land Reform in Latvia]. Riga: Novilkums no Zemkopības ministrijas izdevuma: "Latvijas agrārā vēsture" [Copy of the Edition of the Ministry of Agriculture "The Agrarian History of Latvia], 1930, pp.125-127.

22 Zutis J. 1956, p. 8.

23 Arbusow L. Grundriß der Geschichte Liv-, Est- und Kurlands. Vierte, verbesserte und ergänzte Auflage [The Outline of the History of Livonia, Estonia and Courland. The Fourth Improved and Expanded Edition]. Riga: Verlag von Jonck und Poliewsky, 1918, S. 263.

${ }^{24}$ Hupel A. W. Topographische Nachrichten. Bd. 2 [Topographic News. Vol. 2]. Riga: Johann Friedrich Hartknoch, 1777, S. 127-128

25 Ābers B. 1936, pp. 214-232.

26 Учрежденіе о Курмяндскихъ рестьянахъ [Decree on the Peasants of Courland] (25.08.1817), Art. 43; Положеніе о Аифмянаскихъ крестьянахъ [Regulation on the Peasants of Livonia] (26.03.1819), Art. 72-73.

27 Поможеніе о Иифмяндскихъ крестьянахъ [Regulation on the Peasants of Livonia] (26.03.1819), Art. 72. 
that in the Governorate of Livonia these usually had been farm owners. Electing the civil parish officials was almost the sole task of the parish assembly. ${ }^{28}$ Decisions were adopted by majority vote. In the Governorate of Courland, if servants were invited then farm owners and servants voted separately. In case of a split vote, the final decision was taken by the estate police. ${ }^{29}$

The decisions adopted by peasants were approved by the estate's board (in the Governorate of Livonia) ${ }^{30}$ or the civil parish court/estate police (in the Governorate of Courland).$^{31}$ The estate's supervision was particularly pronounced in the election of officials. Parish elders and parish judges were confirmed into offices by the estate. The estate police (board) could refuse to confirm into office any of the proposed candidates and demand a repeated election. ${ }^{32}$ Disregard for peasants' opinion was not limited to this. As revealed by the research of Assist. Prof. Benno Ābers, the estate police (board) used to confirm into office a person who had received the lowest number of votes. ${ }^{33}$ Significant power of the estate over peasants was retained even after abolition of serfdom.

Henceforth, interests of the civil parish were officially represented by two or three parish elders. ${ }^{34}$ The obligations of an elder were perceived as an office of honour. However, the responsibility was considerable - to be in the know about the parish matters and interests, provide for safety, order, etc. "Authors of the law had intended the elders to be "advocates" (Anwälten) of the civil parish". ${ }^{35}$

The court systems of the 1817 Governorate of Courland and the 1819 Governorate of Livonia were similar. However, certain differences existed. Actually, the Governorate of Livonia retained the system of courts established in the 1804 Law on Peasants in the Governorate of Livonia. The sole difference was that the duties of land courts were taken over by district courts ( уездныцй cyd, Kreisgericht). In difference to the Governorate of Livonia, a two-tier peasant court system was established in the Governorate of Courland - the civil parish court (мірскій суд, Gemeindegericht)

28 Kalninš̌ V. Latvijas PSR valsts un tiesību vēsture. I. Feodālisma un topošā kapitālisma laikmets XI XIX gs. [The History of the State and the Law of the Latvian SSR. I. The Age of Feudalism and Nascent Capitalism XI-XIX c.]. Rigā: Zvaigzne, 1972, p. 264.

29 Учрежденіе о Курмяндскихъ рестьянахъ [Decree on the Peasants of Courland] (25.08.1817), Art. 47.

30 In the Governorate of Livonia, the manor board also performed the duties of the manor police as a general rule. See Положеніе о Иифмянаскихъ крестьянахъ [Regulation on the Peasants of Livonia] (26.03.1819), Art. 134.

31 The civil parish could appeal an estate's decision to Hauptmannsgericht in the governorate of Courland and to Kirchspielsgericht in the Governorate of Livonia. Seе Учрежденіе о Курляндскихъ рестьянахъ [Decree on the Peasants of Courland] (25.08.1817), Art. 48, 49; Положеніе о Аифмянаскихъ крестьянахъ (26.03.1819) [Regulation on the Peasants of Livonia], Art. 78, 80.

32 Учрежденіе о Курмянаскихъ рестьянахъ [Decree on the Peasants of Courland] (25.08.1817), Art. 33; Положеніе о Аифмянаскихъ крестьянахъ (26.03.1819) [Regulation on the Peasants of Livonia], Art. 90, 101.

33 Ābers B. 1936, pp. 188-189.

34 The number of elders could be higher in larger civil parishes. See Mucenieks P. Latvijas pašvaldíbu iekārta [The System of Self-Governments in Latvia]. Rīgā: L. u. Studentu padomes grāmatnīcas izdevums, 1938, p. 123.

35 Ibid., pp. 123-124. 
and district court (Hauptmannsgericht 2ter Abtheilung). The principle introduced by the 1804 Law on Peasants in the Governorate of Livonia that only in the civil parish court all members came from the peasant class was retained in both Governorates. In religious parish courts (Kirchspielsgericht) and in district courts, peasants performed only the duties of assessors. Peasants were not represented in the composition of the higher (revision) court of the Governorate - the (governorate) High Manorial Court (обер-гофгерихт / Oberhofgericht, in Courland) and the (governorate) Manorial Court (zoфzерuxm / Hofgericht, in Livonia). ${ }^{36}$

Civil parish courts heard peasants' civil cases, imposed punishments for transgressions and also attempted to reconcile peasants with landlords. The disputes between peasants and landlords were heard, on their merits, by the district court.

As Melita Mierina's research shows, Latvian peasants usually were attached to "their own piece of land". Therefore, one of the most unpleasant tasks for civil parish courts was evicting unsuccessful tenants from their homes. ${ }^{37}$ Peasant judges had to learn to make not only lawful but also unpopular judgements. Massive responsibility entailed also, for instance, hearing of labour (servitude) disputes ${ }^{38}$, settling the inheritance matters of the civil parish members, ${ }^{39}$ etc. Although under the supervision of estate officials, "emancipation" laws granted rights, imposed obligations, as well taught awareness of the significance of electing civil parish officials.

\section{Enhancing the understanding of democratically legitimate values}

The 1860s are known as the decade of major reforms in the Russian Empire. During the reign of Alexander II Romanov (Александp III Романов) (18551881), on 19 February 1861, serfdom was abolished throughout the Russian Empire, judicial reform was instigated ${ }^{40}$, new regulations on procedural law were

36 Formally, it was possible to request the Ruling Senate to overrule a court's ruling or, with the mediation of the Governorate's government, the Emperor himself. Seе Учрежденіе о Курлянаскихъ рестьянахъ [Decree on the Peasants of Courland] (25.08.1817), Art. 205-214, 373, 392-395, 402-403; Положеніе о Аифмянаскихъ крестьянахъ [Regulation on the Peasants of Livonia], Art. 97-98, 133, 157-182, 183-197, 247.

37 Svarāne M. Saimnieks un kalps Kurzemē un Vidzemē XIX gadsimta vidū (sociālekonomisks pētijums) [The Master and the Servant in Kurzeme and Vidzeme in Mid-XIX Century (Social Economic Study]. Rīga: Zinātne, 1971, p. 85.

38 Švābe A. Drustu pagasta tiesas spriedumi 1830 - 1835 [The Court's Judgements of Drusti Parish Court 1830-1835]. Rīgā: Latvijas Skolotāju Savienība, 1927.

39 See for instance LVVA, 5890. f., 1. apr., 36. 1.

40 Учрежденіе судебныхъ установленій [Establishment of Judicial Institutions] (20.11.1864): Law of the Russian Empire. Полное собраніе законовъ Россійской имперіи [Complete Collection of Laws of the Russian Empire], Собраніе второе [Second Collection], т. XXXIX, Отаеленіе второе [separation of the second], 1864, № 41475. Available at: http://nlr.ru/e-res/law_r/content.html [last viewed August 31, 2019]. 
adopted $^{41}$, etc. The decade of major reforms affected also the Balts. The law, "On Public Administration at the Level of Civil Parishes in the Baltic Provinces" ${ }^{42}$, was adopted on 19 February 1866 (hereafter - the Law of 19 February 1866). The Law of 19 February 1866 altered the relations between the state, estate and civil parish. The aim of the Law of 19 February 1866 was to free civil parish society from tutelage by the estate ${ }^{43}$ and unify administration of civil parishes in the Baltic Governorates.

Experience of nearly 50 years of liberty had demonstrated the ability of Latvian peasants to act and to think independently. Hence, supervision by the estate had become redundant. Religious parish courts (in the Governorate of Livonia) and district court (in the Governorate of Courland) were entrusted with the supervision of the peasant self-governance. Chairmen of the supervisory body were nobles. However, the tie between the estate and the civil parish was severed.

On 9 July 1889, the 20 November 1864 Regulation on Courts of the Russian Empire $^{44}$ (hereafter - the Judicial Reform) was applied to the Baltic Governorates. The aim of the Judicial Reform was separating the competence of the public administration, police and courts. ${ }^{45}$ Thus, the judicial supervision over the civil parishes of the Baltic Governorates contradicted the legal policy of the state. On the basis of the 9 July 1889, Provisional Regulation on Changing the Composition and Jurisdiction of Peasant Bodies, the office of a commissioner for peasant matters

${ }^{41}$ Уставъ уголовнаго судопроизводства [Code on Criminal Proceedings] (20.11.1864): Law of the Russian Empire. Полное собраніе законовъ Россійской имперіи [Complete Collection of Laws of the Russian Empire], Собраніе второе [Second Collection], т. XXXIX, Отделеніе второе [Second Chapter], 1864, № 41476. Available at: http://nlr.ru/e-res/law_r/content.html [last viewed August 31, 2019]; Уставъ гражАанскаго судопроизводства [Code on Civil Proceedings] (20.11.1864). Полное собраніе законовъ Россійской имперіи [Complete Collection of Laws of the Russian Empire], Собраніе второе [Second Collection], т. XXXIX, Отделеніе второе [Second Chapter], 1864, № 41477. Available at: http://nlr.ru/e-res/law_r/content.html [last viewed August $31,2019]$.

42 Положеніе о волостномъ общественномъ управленіи въ Остзейскихъ губерніяхъ [Прибалтійскихъ] [Regulation on Rural Municipality Public Administration in the Ostsee Governorates [Baltic]] (19.02.1866): Law of the Russian Empire. Полное собраніе законовъ Россійской имперіи [Complete Collection of Laws of the Russian Empire], Собраніе второе [Second Collection], т. XLI, отдеменіе первое [Second Chapter], 1866, № 43034. Available at: http://nlr.ru/ e-res/law_r/content.html [last viewed August 31, 2019].

43 Schmidt O. Rechtsgeschichte Liv-, Est- und Curlands [The History of Law of Livonia, Estonia and Courland]. Jurjew (Dorpat): In Commission bei E. J. Karow, 1895, S. 265.

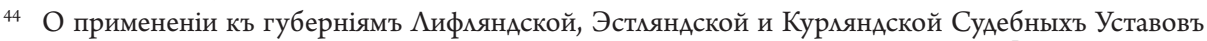
20 ноября 1864 года и о преобразованіи местныхъ кретьянскихъ учрежденій [On Application to the Governorates of Livonia, Estonia and Courland of the Regulation of 20 November 1864 and on the Reform of Local Peasant Bodies]: Law of the Russian Empire. Полное собраніе законовъ Россійской имперіи [Complete Collection of Laws of the Russian Empire], Собраніе третіе [Third Collection], т. IX, 1889, № 6187. Available at: http://nlr.ru/e-res/law_r/content.html [last viewed August 31, 2019].

45 Lazdiņš J. Die Justizreform vom Jahr 1889 und ihre Bedeutung für die Baltischen Provinzen Russlands und (später) Lettland [The Judicial Reform of 1889 and its Significance for the Baltic Governorates of Russia and (Later) Latvia]. In: Schäfer Frank L., Schubert W. (Hrsg.) Judiciary and Judicial System. The $7^{\text {th }}$ Conference in Legal History in the Baltic Sea Area, May 3-5, SchleswigHolstein. Frankfurt am Main: Peter Lang GmbH, PL Academic Research, 2013, S. 94. 
was introduced. ${ }^{46}$ The commissioner for peasant matters was tasked with supervising, whether the parish community applied the laws correctly, and with annulling any illegal decisions. ${ }^{47}$ Assist. Prof. Pēteris Mucinieks has aptly commented on the reduced significance of the estate and the growth of power exerted by the state:

Supervisory bodies had to confirm all officials in their posts. Despite the law stating that conformation could only be denied in cases where electoral procedures were not correctly followed or inappropriate individuals were selected and, therefore, would be denied taking office; in practice confirmation was also refused to individuals who had been correctly elected. The same applied to decisions rescinded based on considerations of relevance. ${ }^{48}$

Due to absence of detailed research, the prevalence of arbitrariness by state officials in peasant matters is not known. Most probably, P. Mucinieks is expressing the social memories retained in inter-war Latvia (1918-1940) about governance in the period of the Russian Empire at the end of the $19^{\text {th }}$ century - beginning of the $20^{\text {th }}$ century. No irrefutable evidence exists regarding the statements by V. Kalninš made during the Soviet period about the commissioners for peasant matters as persons servile before the German nobility. ${ }^{49}$ Indubitably, every reform has its "darker sides". However, the author holds that the positive contribution of the reform to the civil parish administration should not be ignored. Peasant administration of the civil parish was released from direct supervision by the landlord classes. ${ }^{50}$ Henceforth, this task was performed by the state, similarly to the present.

Following the Law of 19 February 1866, a civil parish did not become a territorial body of self-governance. The estate remained outside the civil parish. All peasants registered in the civil parish belonged to the parish community - farm owners (tenants), servants (workers), as well as the persons who, although they did not belong to the peasant class, had obtained title or lease to peasants' plots of lands (houses)..$^{51}$

46 I. O преобразованіи судебной части въ Прибалтійскихъ губерніяхъ и II. О преобразованіи кретьянскихъ присутственных местъ Прибалтійскихъ губерній. Б. Временные правила объ измененіи состава и предметовъ ведомства крестьянскихъ присутственныхъ местъ [I On the Reform of the Judicial Area in the Baltic Governorates and II On Reform of Peasant Representative Bodies in the Baltic Governorates. B. Provisional Rules on the Changes in the Composition and Subject Matters of Peasant Representative Bodies]: Law of the Russian Empire. Полное собраніе законовъ Россійской имперіи [Complete Collection of Laws of the Russian Empire]. Собраніе третіе [Third Collection], т. IX, 1889, № 6188, Art. 1, 8. Available at: http://nlr.ru/e-res/law_r/ content.html [last viewed 31.08.2019].

47 Kalniņ̌̌ V. 1972, pp. 295-296.

48 Mucinieks P. 1938, p. 129.

49 Kalniņš V. 1972, p. 294-295.

50 Положеніе о волостномъ общественномъ управленіи въ губерніяхъ Остзейскихъ [Regulation on Rural Municipality Public Administration in the Ostsee Governorates], Preamble.

51 Mucinieks P. 1938, p. 124. 
The governance of the parish community comprised four bodies:

1) a general civil parish assembly (общій волостной сход) (henceforward the assembly);

2) contingent of deputies (сход выборных);

3) the civil parish elder and his assistants (волостной стариина $c$ помощниками, as well as

4) the civil parish court (волостной суд). ${ }^{52}$

Attendance at the assembly was mandatory for all farm owners (tenants) (hereafter - farm owners) and for every tenth elected representative from among the servants. The latter were sometimes scornfully called a one-tenth of a $\operatorname{man}^{53}$ or flies. ${ }^{54}$ Obviously, only the farm owners were politically full-fledged members of the civil parish. The assembly elected all officials of the civil parish for the term of three years (the civil parish elder, assistants, judges, etc.), and the contingent of deputies. The assembly was competent to decide if it was attended by the civil parish elder and at least a half of the assembly's members. The decisions were adopted by reaching a common agreement or by a majority vote of those present. ${ }^{55}$

In contrast to the emancipation laws, a new body was introduced to ensure governance of the civil parish - the contingent of deputies. The contingent of deputies consisted of the civil parish elder as the chairman and, according to the number of inhabitants in the civil parish, from 4 to 24 elected persons. Farmers and servants elected an equal number of members to the contingent of deputies. Seen in the light of the present practice, these individuals had the same functions as the modern local authority deputies - they decided on dealing with the property of the civil parish, capital, examined complaints and petitions, set wages for the officials, etc. ${ }^{56}$

The Law of 19 February 1866 consolidated the power of the civil parish elder as the sole official. The civil parish elder represented the civil parish, headed the civil parish police, took care of order, welfare of inhabitants, etc. The civil parish elder with his assistants was also the executive body of the civil parish. Only farm owners could be elected to offices of the civil parish elder, an assistant to the elder and the chairman of the civil parish court. ${ }^{57}$

The Law of 19 February 1866, obviously, was not compatible with the spirit of civil society. The classes of inhabitants in the state were not annulled. Inequality in

52 Положеніе о волостномъ общественномъ управленіи въ губерніяхъ Остзейскихъ [Regulation on Rural Municipality Public Administration in the Ostsee Governorates], Art. 4.

53 Mucinieks P. 1938, p. 125.

54 Kalniņš V., Apsitis R. Latvijas PSR valsts un tiesību vēsture. II. [The History of the State and the Law of the Latvian SSR]. Riga: Zvaigzne, 1980, p. 24.

55 Положеніе о волостномъ общественномъ управленіи въ губерніяхъ Остзейскихъ [Regulation on Rural Municipality Public Administration in the Ostsee Governorates], Art. 7.

56 Ibid., Art. 9-12.

57 Estate police had to be informed about the election of an elder and confirmation by the supervisory body was needed. See Положеніе о волостномъ общественномъ управленіи въ губерніяхъ Остзейскихъ [Regulation on Rural Municipality Public Administration in the Ostsee Governorates], Art. 15-24, 26-28. 
rights to stand for offices in the governance and courts of the civil parish existed even within one class of peasants (farmer - servant). The principle of equality of all citizens before the law and the court, inter alia, the principle of gender equality, was embodied only after the Republic of Latvia was proclaimed.

Although the laws on peasants in the Baltics of the $19^{\text {th }}$ century had significant deficiencies, if viewed from the vantage point of the civil society's values, they occupy a permanent place in the history of Latvian law. Before the First World War (1914), the participation of Latvians in municipal governance was insignificant, and Latvians were not represented in the knightly Landtags of the Baltics. "The Basic Laws of the State" 58 (hereafter - the Basic Laws) of the Russian Empire, promulgated on 23 April 1906, envisaged convening a lower chamber of the Parliament of the Russian Empire (Аyмa) (hereafter - the Parliament). Some Latvians also gained the experience of parliamentary work before the Republic of Latvia was proclaimed. Thus, for instance, on 16 February 1912, Andrejs Priedkalns submitted a project of local government, which was later dismissed, envisaging merging all the lands inhabited by Latvians into one administrative-territorial unit. ${ }^{59}$ However, for the most of Latvians, "the schooling in statehood" came through activities in the governance of the civil parish. Aligning the interests of different persons and social classes laid the foundations for the awareness of a democratically organised society.

During the reign of Alexander III Romanov (Александp III Романов) (1881-1894), on 9 July 1889, the Judicial Reform of the Russian Empire was applied to the Baltic Governorates. In the Baltic Governorates, the Judicial Reform was implemented in the framework of Russification policy. ${ }^{60}$ However, the general assessment of the Judicial Reform should not be negative. ${ }^{6}{ }^{1}$ Following the model of the Russian Empire, magistracies and general courts were established in the Baltic Governorates $^{62}$. Moreover, the system of peasant courts in the Baltic Governorates was unified. ${ }^{63}$ The impact of the noble class on peasant courts was eliminated, at least formally. Henceforth, the judicial power itself supervised peasant courts. ${ }^{64}$ Pursuant

58 Основные Государственные Законы [The Basic Laws of the State]: Law of the Russian Empire]: Law of the Russian Empire. Полное собраніе законовъ Россійской имперіи [Complete Collection of Laws of the Russian Empire]. Собраніе третіе [Third Collection], т. XXVI, 1906, № 27805. Available at: http://nlr.ru/e-res/law_r/search.php [last viewed August 31, 2019].

59 Šilde Ā. Pirmā republika. Esejas par Latvijas valsti [The First Republic. Essays on the State of Latvia]. Elpa, 1993, p. 63.

60 Švābe A. Latvijas vēsture. 1800-1914 [The History of Latvia. 1800-1914]. Uppsala: Daugava, 1958, pp. 496-497.

${ }^{61}$ Lazdiņš J. Krievijas impērijas 1864. gada Tiesu reforma un tās nozīme Baltijas guberṇās un vēlāk Latvija [The Judicial Reform of the Russian Empire of 1864 and its Significance in the Baltic Governorates and Later in Latvia]. In: Tiesību efektivitātes piemērošanas problemātika. Latvijas Universitātes 72. zinātniskās konferences rakstu krājums [Papers of the $72^{\text {nd }}$ Scientific Conference of the University of Latvia]. Riga: LU Akadēmiskais apgāds, 2014, pp. 57-68.

${ }_{62}$ General courts included - regional courts, court chamber and the Ruling Senate.

63 II. O преобразованіи кретьянскихъ присутственных местъ Прибалтийскихъ губерний. A. Волостной судебный уставъ (hereafter - Волостной судебный уставъ [Act of civil parish court]). I. Учрежденіе волостныхъ и верхнихъ крестьянскихъ судовъ [Establishment on civil parish court and upper civil parish courts] (hereafter - I.).

64 Ibid., Art. 43. 
to the law policy of the Russian Empire, this symbolised separation between the governance and the judicial power. ${ }^{65}$

The Regulation on Civil Parish Courts established a two-tier court system:

1) civil parish court (волостной суд);

2) civil parish high court (верхний крестьянский суд).

The territorial remit of the civil parish court was not aligned with that of a particular civil parish. Upon the decision by the assembly of magistrates, it could comprise several civil parishes and estate lands adjacent to civil parishes. A single civil parish court was foreseen to be able to deal with issues arising from 1000 to 2000 male souls (inhabitants), and it could not be sited more than 12 versts from the most distant settled place of its territorial remit. ${ }^{66}$

Civil parish judges and candidates for a judge's office were elected through secret ballot for a term of three years at an assembly of a single civil parish (or several). Members of the civil parish court elected the court chairman from their midst. The assembly of magistrates confirmed in post the chairman, judges and candidates for a judge's office after these had been elected. Before assuming the duties of office, a solemn oath had to be given in the presence of a priest or before the civil parish court. $^{67}$ The civil parish court had jurisdiction over petty civil cases and cases of punishable transgressions. ${ }^{6}$ Until 1904, corporal punishments were also applied. ${ }^{69}$

Appeals of decisions taken by a civil parish court could be launched at the civil parish high court. The civil parish high court consisted of a court's chairman, appointed by the Minister for Justice, and invited chairmen of the civil parish courts. A case had to be heard by at least three judges. The assembly of magistrates was responsible for examining complaints about the work of civil parish courts and civil parish high courts. ${ }^{70}$

During the second half of the $19^{\text {th }}$ century, the scope of peasants' property was changing rapidly. Thus, for example, mass-scale purchasing hereditary titles to houses

65 Švābe A. 1958, p. 498.

66 Волостной судебный уставъ [Act of civil parish court]. I., Art. 1-2.

67 Ibid., Art. 7-10, 13, 14.

68 Civil parish courts examined claims amounting up to 100 roubles. Claims derived from title to immovable property were outside the competence of civil parish courts. In cases of punishable transgressions, a civil parish court could apply a monetary fine up to 12 roubles, detention up to seven days, public works and indemnity of losses, corporal punishment up to 20 switches, etc.

See Волостной судебный уставъ [Act of civil parish court]. II. Правима о производстве гражАанскихъ делъ [Rules on the Proceedings in Civil Cases], Art. 7-9, III. Правила о производстве делъ о проступкахъ [Rules on the Proceedings in Cases of Transgressions], Art. 9, IV. Временные Правила о наказаниях, налагаемыхъ Волостными Судами [Provisional Rules on the Punishments Applied by Civil Parish Courts], Art. 1, 3; Положеніе о крестьянахъ

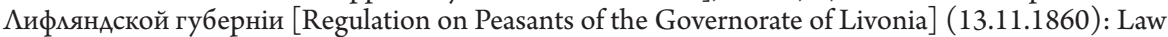
of the Russian Empire. Полное собраніе законовъ Россійской имперіи [Complete Collection of Laws of the Russian Empire]. Собраніе второе [Second Collection], 1860, ОтАеленіе второе [Second Chapter], т. XXXV, № 36312, Art. 1033, 1038, 1040, 1042, 1043 etc. Available at: http:// nlr.ru/e-res/law_r/search.php [last viewed August 31, 2019].

69 Kalniņš V., Apsītis R. 1980, p. 46.

70 Волостной судебный уставъ [Act of civil parish court], I., Art. 29-30, 34, 43. 
(buying the title to land) began. ${ }^{71}$ According to the requirements of the Judicial Reform, claims above 500 roubles and those related to immovable property fell into the jurisdiction of general courts. Materials found in the Latvian State Historical Archive prove that peasants litigated, inter alia, with nobles in general courts. ${ }^{72}$ However, comprehensive studies of the case law of the period of the Russian Empire in the lands inhabited by Latvians are absent. Thus, it is easier to consider the evolution of law than the solutions to collisions of law. One thing, however, is clear - following the abolition of serfdom, the Latvian peasant had obtained not only the right to freedom of movement within the whole territory of the state or to administer justice in lower-instance courts but also to litigate, on equal basis, with any person in any court instance of the Russian Empire. Arguably, this more than anything else taught awareness of rights as a value.

\section{Conclusions}

1. Following the abolition of serfdom in the Baltic Governorates, the genesis and evolution of democratically legitimate understanding amongst the Latvians developed simultaneously with a gradual decrease of the estate's influence on the civil parish community.

2. The governance of a civil parish and the experience of administering justice in lower-instance courts shaped the legal awareness of the majority of Latvians in the spirit of democratic values. Before the Republic of Latvia was proclaimed, no other school of legitimate democracy was available to most of the Latvians.

3. The separation between the civil parish governance and supervision of peasant courts in the second half of the $19^{\text {th }}$ century, as well as the conditional separation of state powers, implemented on the basis of The Basic Law (1906) started shaping awareness of a legitimately organised society on a new level. However, retaining of class laws precludes discussions about the development of civil society before the First World War (1914).

\section{BIBLIOGRAPHY}

\section{Literature}

1. Ābers B. Vidzemes zemnieku stāvoklis 19. gs. pirmā pusē [The Situation of Vidzeme's Peasants in the First Half of the $19^{\text {th }}$ Century]. Rĩgā: Izdevusi grāmatu apgādniecība, A. Gulbis, 1936.

2. Ābers B. Vidzemes zemnieku "putna brīvība" pēc 1819. g. likuma ["The Bird's Freedom" of Vidzeme's Peasants after the Law of 1819]. Tieslietu Ministrijas Vēstnesis [Herald of the Ministry of Justice], No. 3, 1936.

71 Švābe A. 1958, pp. 314-329.

72 See for instance LVVA 115. f., 4. apr., 48. 1.; LVVA 770. f., 6. apr., 32. 1.; LVVA 770. f., 6. apr., 348. 1. etc. 
3. Arbusow L. Grundriß der Geschichte Liv-, Est- und Kurlands. Vierte, verbesserte und ergänzte Auflage [The Outline of the History of Livonia, Estonia and Courland. The Fourth Improved and Expanded Edition]. Riga: Verlag von Jonck und Poliewsky, 1918.

4. Bušs O., Jansone I. Ieskats latviešu valodas vēsturē (no pirmsākumiem līdz 20. gadsimtam) [Insight into the History of the Latvian Language (from Origins to the $20^{\text {th }}$ Century)]. In: Latvija un latvieši [Latvia and Latvians]. II sējums [Vol. II]. Rīga: Latvijas Zinātṇu akadēmija [Latvian Academy of Science], Vol. II, 2018, pp. 114-148.

5. Dunsdorfs M. Baltijas muižnieciba laikmetu maiñā [The Baltic Nobility in the Change of an Era] Rīga: Zinātne, 1986.

6. Hupel A. W. Topographische Nachrichten. Bd. 2 [Topographic News. Vol. 2]. Riga: Johann Friedrich Hartknoch, 1777.

7. Kalniņš V. Latvijas PSR valsts un tiesību vēsture. I. Feodālisma un topošã kapitālisma laikmets XI-XIX gs. [The History of the State and the Law of the Latvian SSR. I. The Age of Feudalism and Nascent Capitalism XI-XIX c.] Rīgā: Zvaigzne, 1972.

8. Kalniņš V., Apsītis R. Latvijas PSR valsts un tiesību vēsture. II [The History of the State and the Law of the Latvian SSR]. Riga: Zvaigzne, 1980.

9. Lazdiņš J. Abolition of serfdom and organisation of civil parish communities. In: Latvia and Latvians. Riga: Latvian Academy of Science, 2018, Vol. II, pp. 276-308.

10. Lazdiņš J. Dzimtbūšanas atcelšana, pagasta sabiedrības organizācija un nacionāli valstiskas domāšanas pirmsākumi [Abolition of Serfdom, Organisation of Parish Society and the Origins of Nation-State Thinking]. In: Latvieši un Latvija. II sējums. Valstiskums Latvijā un Latvijas valsts - izcīnìtā un zaudētā. [Latvians and Latvia. Vol. II. Statehood in Latvia and the State of Latvia - Won and Lost] Rīga: Latvijas Zinātn̦u akadēmija [Latvian Academy of Science], 2013, pp. 173-196.

11. Lazdiņš J. Die Justizreform vom Jahr 1889 und ihre Bedeutung für die Baltischen Provinzen Russlands und (später) Lettland [The Judicial Reform of 1889 and its Significance for the Baltic Governorates of Russia and (Later) Latvia]. In: Schäfer Frank L., Schubert W. (Hrsg.) Judiciary and Judicial System. The $7^{\text {th }}$ Conference in Legal History in the Baltic Sea Area, May 3-5, Schleswig-Holstein. Frankfurt am Main: Peter Lang GmbH, PL Academic Research, 2013.

12. Lazdiņš J. Krievijas impērijas 1864. gada Tiesu reforma un tās nozīme Baltijas guberņās un vēlāk Latvijā. In: Tiesību efektivitātes piemērošanas problemātika [The Judicial Reform of the Russian Empire of 1864 and its Significance in the Baltic Governorates and Later in Latvia]. Latvijas Universitātes 72. zinātniskās konferences rakstu krājums. Rīga [Papers of the $72^{\text {nd }}$ Scientific Conference of the University of Latvia]: LU Akadēmiskais apgāds, 2014.

13. Mucenieks P. Latvijas pašvaldību iekārta [The System of Self-Governments in Latvia]. Rīgā: L. u. Studentu padomes grāmatnīcas izdevums, 1938.

14. Prutz H. Der Kampf um die Leibeigenschaft in Livland [The Struggle for Serfdom in Livonia]. München: Verlag der Königlich Bayerischen Akademie der Wissenschaften, 1916.

15. Schmidt O. Rechtsgeschichte Liv-, Est- und Curlands [The History of Law of Livonia, Estonia and Courland]. Jurjew (Dorpat): In Commission bei E. J. Karow, 1895.

16. Seraphin E. Geschichte Liv-, Est- und Kurlands von den "Aussegelung" des Landes bis zur Einverleibung in das russische Reich. I. Band. Die Zeit bis zum Untergang livländischer Selbständigkeit [History of Livonia, Estonia and Courland from the "discovering" of the country to its incorporation into the Russian Empire. I. volume. The time until the loss of independence of Livonia]. Reval: Verlag von Franz Kluge, 1895. 
17. Sivers J. von. Zur Geschichte der Bauernfreiheit in Livland [On the History of Peasant Freedom in Livonia]. Riga: Nicolai Kymmel's Buchhandlung, 1878.

18. Svarāne M. Saimnieks un kalps Kurzemē un Vidzemē XIX gadsimta vidū (sociālekonomisks pētijums) [The Master and the Servant in Kurzeme and Vidzeme in Mid-XIX Century (Social Economic Study]. Rīga: Zinātne, 1971.

19. Šilde Ā. Pirmā republika. Esejas par Latvijas valsti [The First Republic. Essays on the State of Latvia]. Elpa, 1993.

20. Švābe A. Drustu pagasta tiesas spriedumi 1830-1835 [The Court's Judgements of Drusti Parish Court 1830-1835]. Rìgā: Latvijas Skolotāju Savienība, 1927.

21. Šterns I. Latvijas vēsture. 1180-1290. Krustakari [The History of Latvia 1180-1290. Crusades]. Rịga: Latvijas vēstures institūta apgāds, 2002.

22. Švābe A. Zemes attiecības un zemes reformu vēsture Latvijā [Land Relationships and the History of Land Reform in Latvia]. Rīga: Novilkums no Zemkopības ministrijas izdevuma: "Latvijas agrārā vēsture [Copy of the Edition of the Ministry of Agriculture "The Agrarian History of Latvia]”, 1930.

23. Švābe A. Latvijas vēsture. 1800-1914 [The History of Latvia. 1800-1914]. Uppsala: Daugava, 1958.

24. Tobien A. Die Agrargesetzgebung Livlands im 19. Jahrhundert. I. Band: Die Bauerverordnung von 1804 und 1809 [The Agricultural Legislation of Livonia in the $19^{\text {th }}$ Century. Vol. I: The Peasant Law of 1804 and 1809]. Berlin: Puttkammer \& Mühlbrecht, 1899.

25. Vīgrabs J. Landrāta Rozena 1739. gada deklarācija par Vidzemes dzimtkungu tiesībām uz zemnieku miesu un mantu [The Declaration of Landrat Rosen of 1739 on the Rights of Vidzeme Feudal Lords to the Body and Property of Peasants]. Riga: A. Gulbis, 1937.

26. Zutis J. Vidzemes un Kurzemes zemnieku brīvlaišana XIX gadsimta 20. gados [Setting Free of Vidzeme and Kurzeme Peasants in the 20s of XIX Century]. Rigā: Latvijas Valsts izdevniecỉba, 1956.

\section{Legislative acts}

1. Latvijas pilsoniem! [To the Citizens of Latvia!] (18.01.1918): Declaration by the Republic of Latvia. Pagaidu Valdíbas Vēstnesis [Herald of the Provisional Government], 1918. g. 14. (1.) decembrī, Nr. 1.

2. Latvijas Tautas padomes politiskā platforma [The Political Platform of the Latvian People's Council] (18.01.1918): The Provisional Law of the Republic of Latvia. Pagaidu Valdibas Vēstnesis [Herald of the Provisional Government], 1918. g. 14. (1.) decembrī.

3. Положеніе о крестьянахъ Аифмянаской губерніи [Regulation on the Peasants of the Governorate of Livonia] (20.02.1804): Law of the Russian Empire. Полное собраніе законовъ Россійской имперіи съ 1649 года [Complete Collection of Laws of the Russian Empire since 1649], 1804-1805, т. XXVIII, № 21162. Available at: http://nlr.ru/e-res/ law_r/content.html [last viewed August 31, 2019].

4. Учрежденіе о Курмяндскихъ крестьянахъ / Kurländische Bauer-Verordnung [Decree on the Peasants of Courland] (25.08.1817) Law of the Russian Empire. Полное собраніе законовъ Россійской имперіи, съ 1649 года [Complete Collection of Laws of the Russian Empire since 1649] 1817. т. XXXIV. № 27024. Available at: http://nlr.ru/e-res/law_r/ content.html [last viewed August 31, 2019].

5. Положеніе о Аифмянаскихъ крестьянахъ / Liefländische Bauer-Verordnung [Regulation on the Peasants of Livonia] (26.03.1819): Law of the Russian Empire. Полное собраніе 
законовъ Россійской имперіи, съ 1649 гоАа. [Complete Collection of Laws of the Russian Empire since 1649] 1819. т. XXXVI. № 27735. Available at: http://nlr.ru/e-res/law_r/ content.html [last viewed August 31, 2019].

6. Положеніе о крестьянахъ Аифмянаской губерніи [Regulation on the Peasants of the Governorate of Livonia] (13.11.1860): Law of the Russian Empire. Полное собраніе законовъ Россійской имперіи. Собраніе второе [Complete Collection of Laws of the Russian Empire. Second Collection]. 1860. Отделеніе второе [Second Chapter]. т. XXXV, № 36312, Available at: http://nlr.ru/e-res/law_r/search.php [last viewed August $31,2019]$.

7. Манифест. - О Всемилостивейшемъ дарованіе крепостнымъ мюАямъ правъ состоянія свободныхъ сельскихъ обыватемей, и объ устройстве ихъ быта [Manifesto. - On the AllGracious Granting to the Serfs of the Right to the Status of Free Rural People and Their Living Conditions] (19.02.1861): Law of the Russian Empire. Полное собраніе законовъ Россійской имперіи. Отдемение первое [Complete Collection of Laws of the Russian Empire. First Chapter]. 1861. т. XXXVI. № 36650. Available at: http://nlr.ru/e-res/law_r/ content.html [last viewed August 31, 2019].

8. Учрежденіе судебныхъ установленій [Establishment of Judicial Institutions] (20.11.1864): Law of the Russian Empire. Полное собраніе законовъ Россійской имперіи [Complete Collection of Laws of the Russian Empire]. Собраніе второе [Second Collection]. т. XXXIX. ОтАеленіе второе [Second Collection], 1864. № 41475. Available at: http://nlr.ru/e-res/ law_r/content.html [last viewed August 31, 2019].

9. Уставъ уголовнаго судопроизводства [Code on Criminal Proceedings] (20.11.1864): Law of the Russian Empire. Полное собраніе законовъ Россійской имперіи [Complete Collection of Laws of the Russian Empire]. Собраніе второе [Second Collection], т. XXXIX. Отдеменіе второe [Second Chapter]. 1864. № 41476. Available at: http://nlr.ru/e-res/law_r/content. html [last viewed August 31, 2019].

10. Уставъ гражАанскаго судопроизводства [Code on Civil Proceedings] (20.11.1864): Law of the Russian Empire. Полное собраніе законовъ Россійской имперіи [Complete Collection of Laws of the Russian Empire]. Собраніе второе [Second Collection], т. XXXIX. Отдеменіе второe [Second Chapter]. 1864. № 41477. Available at: http://nlr.ru/e-res/law_r/content. html [last viewed August 31, 2019].

11. Положеніе о волостномъ общественномъ управленіи въ Остзейскихъ губерніяхъ [Прибалтійскихъ] [Regulation on Rural Municipality Public Administration in the Ostsee Governorates [Baltic] (19.02.1866): Law of the Russian Empire. Полное собраніе законовъ Россійской имперіи [Complete Collection of Laws of the Russian Empire]. Собраніе второе [Second Collection], т. XLI, отдеменіе первое [Second Chapter], 1866, № 43034. Available at: http://nlr.ru/e-res/law_r/content.html [last viewed August 31, 2019].

12. О примененіи къ губерніямъ Иифмянаской, Эстмянаской и Курмянаской Судебныхъ Уставовъ 20 ноября 1864 года и о преобразованіи местныхъ кретьянскихъ учрежденій [On Application to the Governorates of Livonia, Estonia and Courland of the Regulation of 20 November 1864 and on the Reform of Local Peasant Bodies]: Law of the Russian Empire. Полное собраніе законовъ Россійской имперіи [Complete Collection of Laws of the Russian Empire]. Собраніе третіе [Third Collection], т. IX, 1889, № 6187. Available at: http://nlr.ru/e-res/law_r/content.html [last viewed August 31, 2019].

13. I. О преобразованіи судебной части въ Прибалтійскихъ губерніяхъ и II. О преобразованіи кретьянскихъ присутственных местъ Прибалтійскихъ губерній [On the Reform of the Judicial Area in the Baltic Governorates and II On Reform of Peasant Representative Bodies in the Baltic Governorates. Полное собраніе законовъ Россійской имперіи 
[Complete Collection of Laws of the Russian Empire]. Собраніе третіе [Third Collection], т. IX, 1889, № 6188. Available at: http://nlr.ru/e-res/law_r/content.html [last viewed August 31, 2019].

14. Основные Государственные Законы [The Basic Laws of the State]: Law of the Russian Empire. Полное собраніе законовъ Россійской имперіи [Complete Collection of Laws of the Russian Empire]. Собраніе третіе [Third Collection], т. XXVI, 1906, № 27805. Available at: http://nlr.ru/e-res/law_r/search.php [last viewed August 31, 2019].

\section{Archival materials}

1. Latvijas Valsts Vēstures arhīvs [The National Archives of Latvia] (hereafter - LVVA), 115. fonds (hereafter - f.), 4. apraksts (hereafter - apr.), 48. (hereafter -1 .).

2. LVVA, 770. f., 6. apr., 32. 1 .

3. LVVA, 770. f., 6. apr., 348. 1.

4. LVVA, 1307. f., 1. apr., 327.1.

5. LVVA, 5890. f., 1. apr., 36. 1. 